\title{
Pengembangan Buku Ajar IPA Terpadu SMP berbasis Eksperimen
}

\author{
Matsun $^{1]}$, Lia Anggraeni ${ }^{2]}$, Eka Trisianawati ${ }^{3]}$ \\ IKIP PGRI Pontianak \\ E-mail: ${ }^{1]}$ matsunzaidan@gmail.com \\ ${ }^{2]}$ lia060786@gmail.com \\ 3] trisianawatieka@gmail.com
}

\begin{abstract}
Abstrak
Ilmu alam atau Ilmu Pengetahuan Alam (IPA) merupakan ilmu yang mencari tahu tentang alam beserta isinya secara logis sehingga IPA bukan hanya penguasaan ilmu pengetahuan, tetapi juga merupakan suatu proses penyelidikan dan penemuan (inkuiri). Bahan ajar yang bersifat terpadu (tidak terpisah) sangat bermanfaat untuk menunjang proses pembelajaran IPA Terpadu di SMP/MTs. Tujuan utama penelitian ini adalah untuk mengetahui: (1) Bagaimana kelayakan buku ajar IPA terpadu SMP Kelas VII berbasis eksprimen berdasarkan ahli materi, (2) Bagaimana kelayakan buku ajar IPA terpadu SMP Kelas VII berbasis eksprimen berdasarkan ahli media. Penelitian dan pengembangan modul IPA terpadu ini menggunakan prosedur 4-D Models yang terdiri dari 4 tahap yaitu tahap pendefinisian (define), tahap perancangan (design), tahap pengembangan (develop), dan tahap pendistribusian (disseminate). Analisis data yang digunakan selama proses penelitian dan pengembangan adalah analisis deskriptif, analisis kelayakan buku ajar berdasarkan skor criteria. Hasil penelitian menunjukkan: (1) Buku ajar IPA terpadu SMP berbasis eksprimen yang telah di validasi oleh ahli materi dengan keteria layak digunakan dengan nilai rata-rata 72.17. (2) Buku ajar IPA terpadu SMP berbasis eksprimen yang telah di validasi oleh ahli media dengan keteria layak digunakan dengan nilai rata-rata 75.14. Berdasarkan hasil analisis data disimpulkan bahwa pengembangan buku ajar IPA terpadu SMP berbasis eksprimen layak digunakan di sekolah. Buku ajar IPA terpadu SMP berbasis eksprimen telah di ajukan ISBN dan dicetak.
\end{abstract}

Kata kunci: Buku ajar, IPA Terpadu, Eksperimen.

\section{Development of Middle School Integrated Science Textbooks Experimental Based}

\begin{abstract}
Natural science or natural science (IPA) is a science that seeks to know about nature and its contents logically so that science is not only mastery of science, but also a process of inquiry and discovery (inquiry). Integrated teaching material (not separate) is very useful to support the Integrated Science learning process in SMP / MTs. The main purpose of this study was to find out: (1) How is the feasibility of integrated science-based SMP VII grade textbooks based on material experts, (2) How is the feasibility of integrated science-based SMP VII grade textbooks based on media experts. The research and development of this integrated science module uses the procedure of
\end{abstract}


4-D Models which consists of four stages, namely the stage of defining, designing, developing and distributing. Analysis of the data used during the research and development process is descriptive analysis, analysis of the feasibility of teaching books based on criteria scores. The results of the study show: (1) experiment-based SMP integrated textbooks that have been validated by material experts with appropriate skills are used with an average value of 72.17. (2) Integrated science-based junior high school textbooks that have been validated by media experts with cheerfulness to be used with an average value of 75.14. Based on the results of data analysis, it was concluded that the development of integrated science-based teaching books for junior high schools was appropriate for use in schools. Integrated science-based SMP science textbooks have been submitted ISBN and printed.

Keywords: Textbooks, Integrated science, Experiments

\section{PENDAHULUAN}

Bertepatan dengan maraknya perkembangan teknologi, pembelajaran dikelas juga harus mengalamai perkembangan dan perubahan yang signifikan. Kegiatan pembelajaran dikelas yang biasanya tertumpu kepada pendidik (guru) dan peserta didik (siswa) hanya sebagai pendengar, dengan kemajuan teknologi peran siswa lebih dominan dibandingkan dengan peran guru. Guru di tuntut hanya sebagai fasilitator pembelajaran dikelas dan proses pembelajaran di kelas didominasi oleh siswa. Dengan perkembangan teknologi siswa bisa mencari informasi mengenai materi yang akan disampaikan. Proses interaksi antara dosen dan guru di kelas semacam itu justru menjadi indikasi keberhasilan proses pembelajaran di sekolah. Kegiatan pembelajaran dikelas bukan hanya tertumpu kepada pendidik (guru) tetapi harus tertumpu kepada peserta didik (siswa).

Peserta didik (siswa) merupakan komponen utama dalam pembelajaran di kelas. Pembelajaran dikelas melibatkan siswa, guru, dan ketersediaan sarana dan prasarana. Pembelajaran yang ideal apabila tiga komponen (siswa, guru, dan sarana prasarana) terpenuhi. Latar belakang siswa sangat menentukan kualitas pendidikan di suatu sekolah, siswa yang memiliki latar belakang kemampuan akademik baik akan berdamfak terhadap proses pembelajaran. Siswa yang berasal dari lulusan SD favorit akan memiliki kemampuan belajar yang baik di dalam kelas. Ssiwa lebih mudah menerima materi yang disampaikan oleh guru di kelas. Siswa lebih mudah berkomunikasi dengan guru berkaitan materi yang disampikan di kelas.

Guru yang berkualitas merupakan guru yang memiliki kemampuan dalam menyempaikan materi di kelas. Kemampuan guru dalam menyampaiakn materi dikelas di dukung oleh latar belakang pendidikan guru tersebut. Guru lulusan S1 pendidikan Bahasa Indonesia seharusnya mengajar mata pelajaran Bahasa Indonesia di sekolah tersebut, tetapi kenyataan banyak di temukan khususnya di Kalimantan Barat guru Bahasa Indonesia yang mengajar IPA (Ilmu Pengetahuan Alam). Hal ini terjadi karena keterbatasan ketersedian guru IPA (Ilmu Pengetahuan Alam) di Kalimantan Barat. Hal tesebutlah membuat mutu dan kualiatas pembelajaran di kelas menjadi kurang maksimal. Ironisnya ada beberapa 
sekolah di daerah terpencil Kalimantan Barat hanya memiliki satu orang guru lulusan S1 sedangkaan guru yang lain lulusan SMA/ sederajat. Kualitas pendidikan di daearah terpencil Kalimantan Barat sangat lemah. Penerapan media, model, metode pembelajaran di daerah terpencil tidak pernah terwujud. Guru datang ke sekolah itu sudah cukup bagi mereka. Pembelajaran di kelas hanya menggunakan pembelajaran konvensioanal. Dengan lulusan guru tamatan SMA membuat proses pembelajaran yang di inginkan oleh pemerintah jauh dari harapan. Jumlah guru yang tidak sesuai dengan rasio siswa juga menjadi masalah, jumlah siswa lebih banyak di bandingkan dengan jumlah guru, di satu sekolah hanya terdapat satu orang guru yang berstatus ASN (Aparatur Sipil Negara) sisanya guru honor BOS (Bantuan Operasional Sekolah) dimana, proses pembelajaran di sekolah harus berjalan dengan lancar siswa harus mendapat pendidikan yang layak.

Sarana dan prasarana sekolah sangat mendukung proses pembelajaran di kelas. Idealnya sekolah yang memiliki sarana dan prasarana yang lengkap akan membuat kualitas siswa baik. Berkaitan dengan sarana dan prasarana daerah terpencil di Kalimantan Barat memiliki sarana dan prasarana jauh dari yang di inginkan. Salah satu sarana dan prasarana yang masih belum terjangkau di sekolah adalah listrik. Listrik merupakan hal yang pokok yang wajib ada di sekolah. Banyak sekali sekolah di daerah yang tidak memiliki listrik. Sinyal HP juga tidak terdapat di daerah yang berakibat komunikasi sangat terhambat, apalagi kalua bercerita tentan revolusi industrin 4.0 yang syarat dengan teknologi informasi, didaeah sangat jauh dari harapan. Akses menuju sekolah ynag sangat jauh di dukung dengan jalan yang tidak memadai. Untuk menuju ke sekolah diperlukan waktu kuarang lebih 4 jam perjalanan menggunakan sepeda motor. Jalan yang di lewati melintasi bukit, lembah, hutan, dan pemukiman masyrakat. Jalan yang di lewati masih menggunkaan jalan masyarakat (jalan tikus) hal tersebut membuat guru tidak mau ditempatkan di sekolah tersebut. Kurang tersedianya air bersih juga menghambat pembejaran dikelas. Siswa banyak tertular penyakit karena airnya tidak bersih. Sarana dan parsana lainnya seperti kurangnya ruang kelas, tidak adanya ruang laboratorium, ruang UKS, dan wc tidak berfungsi secara optimal membuat pembelajaran di kelas tidak berjalan dengan bai. Proses pembelaran di kelas harus terlaksana dengan baik.

Perubahan proses pembelajaran di kelas, merupakan hal yang biasa dan bisa di hindari. Hal ini dikarenakan proses pembelajaran dari masa ke masa sesuai dengan waktunya. Pada saat sekarang ini, memiliki pengetahuan tidak menjadi jaminan untuk seorang lulusan untuk mendapatkan pekerjaan. Yang diperlukan pada saat ini adalah keahlian khusus yang sejalan dengan kebutuhan yang ada di di masyarakat. Jika tidak bisa bersaing, maka lulusan pendidikan hanya menjadi penonton dan tidak bisa bersaing. Dimana pada saat ini guru harus mempunyai literasi baru yang diperlukan yaitu literasi data, literasi teknologi, dan literasi manusia.

Pendidikan 4.0 merupakan pengaruh utama dari era revolusi industry 4.0. Dengan terjadinya era revolusi industry 4.0 dunia mengalamai perubahan yang sangat signifikan terutama dalam dunia pendidikan. Proses belajar dan mengajar sudah mengarah ke teknologi. Banyak sekali menggunakan media pembelajaran yang berbasis teknologi.

Proses pembelajaran pada era pendidikan 4.0 sangat berpengaruh terhadap proses pembelajaran di kelas. 
Guru diharapkan mampu menguasai media pembelajaran yang efektif dan inovatif. Pembelajaran menggunakan media pembelajaran yang berteknologi membuat siswa lebih tertarik dan membuat siswa senang belajar dengan media pembelajaran.

Era revolusi industry 4.0 memiliki ciri utama dimana pada era ini teknologi informasi sebagai pemeran utama dalam kehidupan manusia. (Kemristekdikti, 2018). Menyiapkan lulusan yang berkualitas dan mampu bersaing secara global, dan menguasai perkembangan teknologi merupakan hal yang penting untuk semua orang dan penting bagi masa depan suatu negara (Kanematsu \& Barry, 2016). Perguruan tinggi harus mampu mempersiapkan lulusan yang memiliki keterampilan dan keahlian sehingga lulusan dapat bersaing secara gelobal.

Terkait dengan konteks

amanat Peraturan Presiden Nomor 2 Tahun 2015 tentang Rencana Pembangunan Jangka Menengah Nasional (2015-2019) yang menyatakan bahwa peran ilmu pengetahuan dan teknologi diharapkan berkontribusi secara signifikan terhadap perekonomian nasional (Kemristekdikti, 2017). Oleh karena itu, peningkatan kualitas pembelajaran sains adalah salah satu tantangan bagi para dosen di program Studi Pendidikan Sains. Sejalan dengan alasan ini (Susilo, 2014) menyatakan bahwa dosen dihadapkan pada tantangan bagaimana mempersiapkan calon guru Pendidikan Fisika (sains) profesional, yang adaptif terhadap perkembangan zaman. Adaptif berarti dapat beradaptasi dengan tuntutan perkembangan ilmu pengetahuan dan teknologi. Kualitas guru tergantung pada kualitas dosen, guru yang baik diciptakan oleh dosen yang baik juga. Dengan ini, dosen harus dapat memberikan bekal kepada calon guru dalam menghadapi era revolusi industri 4.0.

Lembaga Pendidik dan Tenaga Kependidikan (LPTK) IKIP-PGRI Pontianak adalah lembaga pendidikan yang fokus pada percetakan guru di Kalimantan Barat, dalam kurikulum 2013 Sekolah Menengah (SMP) memposisikan pembelajaran sains sebagai salah satu mata pelajaran utama, karena penuh dengan persyaratan sains dan teknologi. sangat disayangkan bahwa tingkat pemahaman konsep dan prestasi belajar mata pelajaran ini masih rendah.

Berdasarkan hasil observasi, siswa mengalami kejenuhan dari buku IPA terpadu yang digunakan, dimana buku IPA terpadu tidak sesuai dengan kondisi alam siswa yang ada di Kalimantan Barat. Buku IPA terpadu yang di buat oleh penerbit di luar Kalimantan Barat menceritakan konsep yang susah dipahami oleh siswa dimana siswa sulit untuk membayangkan apa yang tertulis di dlaam buku ajar IPA terpadu tersebut. Sebagai contoh di buku IPA terpadu di tulis mengenai kereta api sedangakan siswa belum pernah melihat secara lansung kereta api.

Buku IPA (Ilmu Pengetahuan Alam) terpadu yang terdapat disekolah merupakan buku ajar yang dimiliki seolah yang pembeliannya menggunakan uang bos. Buku IPA terpadu yang terdapat disekolah seluruhnya bearsal dari penerbit yang penulisnya bukan berasal dari penulis Kalimantan Barat. Sehingga konsep yang disampaikan kurang bermakna bagi siswa. Siwa kurang tertarik dengan konten beserta isi yang terdapat dalam buku ajar IPA terpadu yang disediakan oleh sekolah. Hal inilah yang membuat pembelajaran di sekolah kurang diminati siswa. Siswa tidak bisa membayangan apa yang tertulis di dalam buku tersebut sehingga siswa 
sulit dalam memahami konsep pembelajaran IPA terpadu di SMP.

Pemahaman konsep yang dialami siswa dikarenakan oleh keterbatasan ketersediaan media pembelajaran IPA yang tepat, karena proses pembelajaran merupakan suatu proses pendidikan yang dilakukan oleh pendidik kepada peserta didik. Pendidik (guru) berperan aktif dalam memberikan pembelajaran menggunakan media pembelajaran. Media pembelajaran ada yang berbentuk riil dan ada juga yang menggunakan virtual. Media pembelajaran yang digunakan salah satu diantaranya adalah buku ajar. Buku ajar IPA terpadu berbasis eksprimen. Buku ajar yang dikembangkan memuat kearifan local Kalimantan Barat.

Inti pengajaran yang baik dengan teknologi adalah mencakup komponen yang paling utama yaitu, komponen pedagogi, teknologi, dan konten. Interaksi antara dan di antara ketiga komponen tersebut, yang dimainkan secara berbeda di berbagai konteks, memperhitungkan variasi keluasan dan kedalaman materi dan kualitas integrasi teknologi pendidikan. Ketiga basis pengetahuan (konten, pedagogi, dan teknologi) ini merupakan inti dari kerangka pengetahuan Teknologi, Pedagogi, dan Konten (TPACK).

Hasil penelitian menunjukkan salah satu penyebab yang menyebabkan meningkatkan kemampuan para pendidik merupakan kemampuan pendidik dalam mengkombinasikan antara komponen pedagogi, teknologi, dan konten. Calon pendidik Pendidikan fisika perlu diberi bekal pengetahuan, dan keterampilan dalam mendesain, merencanakan pembelajaran, mengelola kelas yang efektif, memilih dan memanfaatkan media dan bahan ajar, mampu mengembangkan bahan ajar yang sesuai, serta mengembangkan instrumen untuk penilaian. Pengetahuan dan keterampilan tersebut tercakup dalam mata pelajaran IPA terpadu disekolah.

Pembelajaran IPA Terpadu yaitu pembelajaran yang menghubungkan antara tiga rumpun ilmu. Siswa diajarkan dalam memehami konsep yang ada alam semesta. IPA merupakan suatu kajian yang sangat penting karena banyak sekali konsep-konsep yang berkaiatan dengan alam yang terdapat dalam IPA yang bisa di jelaskan.

Proses keberlangsungan pembelajaran IPA terpadu, sangat dipengaruhi oleh kesiapan guru dan kesiapan siswa. Guru harus siap materi dan media pembelajaran, selian itu siswa harus siap menerima materi yang kan di sampaikan oleh guru. Salah satu media pembelajaran yang utama adalah buku ajar, menurut Budi Setyawan (2012) Buku ajar merupakan gumpulan materi-materi yang memuat indicator, tujuan, materi, soal, dan rangkuman ynag di buat oleh ahlinya.

Buku ajar, Pedoman Pembelajaran, dan media pembelajaran merupakan termasuk kepada perangkat pembelajaran. Buku yang dibuat oleh ahlinya dan di gunakan oleh siswa disebut buku ajar. Buku ajar dapat digunakan oleh siswa kapan dan dimanapun siswa berada. Baik siswa berada di kelas maupun berada di rumah. Siswa dengan bebas bisa menggukan dan membawa buku ajar IPA terpadu. Siswa bisa menulis langsung jawaban soal dibuku ajar. Pedoman pembelajaran merupakan panduan yang memiliki tahapn-tahapan penggunaan buku yang digunakan oleh guru serta jawaban dari soal yang ada di buku ajar atau disebut juga dengan buku pegangan untuk guru, dan instrumen penilaian pembelajaran.

Buku ajar dan pedoman pembelajaran IPA terpadu berbasis ekperimen dikembangkan harus sesuai dengan ciri khas Kalimantan Barat, 
sehingga siswa lebih tertarik dan minat untuk belajar IPA dan siap untuk menghadapai era revolusi industri 4.0. Dengan demikian, pengembangan buku ajar dan pedoman pembelajaran IPA terpadu berbasis eksperimen harus di sesuaikan dengan karakteristik siswa di daerah Kaliamantan Barat.

Ilmu alam merupakan ilmu yang membahas tentang konsep-konsep yang memuat materi, konsep, rekasi bahan, makhluk hidup besrta isinya yang ada di semesta alam. Pembelajaran ini bertujuan agar siswa lebih mencintai alam beserta isinya, memiliki rasa ingin tahu. Sehingga siswa lebih termotifasi dalam belajar. Dengan harapan hasil belajar siswa lebih baik.

Terlaksananya kegiatan belajar IPA terpadu SMP/MTs tidak bisa terpisah dengan alam. Kegiatan belajar IPA tidak terfokus di dalam kelas tetapi lebih hars lebih banyak berada di alam. Pembelajaran IPA yang dijarkan di alam memiliki keutamaan yang sangat penting salah satunya adalah menghilangkan kebosanan dan membuat siswa lebih cinta terhadap alam beserta isinya. Berdasarkan teori belajar, pembelajaran yang langsung dirasakan oleh siswa akan membuat pembelajaran terkesan. Dengan pembelajaran IPA yang menerapkan secara langsung konsep alam membuat siswa memiliki pengalaman yang membekas dalam ingatannya.

$$
\text { K-13 Revisi merupakan }
$$

kurikulum wajib yang di terapkan di sekolah. Kurikulum 2013 revisi merupakan hasil evaluasi dari kurikulum 2013 yang berfokus kepada perkembangan peserta didik. Luaran yang diharapkan tidak lagi terfokus kepada hasil belajar melainkan kepada sikap dan karakter siswa. Kurikulum K13 Revisi ini menuntut guru berperan aktif dalam proses pembelajaran guru harus lebih inovatif dan kreatif dalam menyampaikan pembelajaran di kelas, untuk mencapai target yang diharapkan saat awal proses pembelajaran pembelajaran dikelas. Untuk mencapai target tersebut, salah satunya langkah yang dilakukan adalah dengan mengaktifkan lagi kegiatan pembelaajran di dalam laboratorium atau praktikum dalam proses pembelajaran IPA. Departemen Pendidikan Nasional (2010) menyatakan bahwa "fungsi dari ruangan laboratorium sains adalah sebagai tempat pembelajaran, tempat peragaan dan tempat praktek sains". Terdapat empat alasan pentingnya kegiatan praktikum IPA. Pertama, praktikum IPA menunjang materi Kedua, praktikum menjadi wahana pendekatan ilmiah. Ketiga, membangkitkan motivasi belajar IPA, Keempat, praktikum IPA mampu mengembangkan kemampuan dasar melakukan eksperimen.

Permendiknas Nomor 22 Tahun 2010 menerangkan IPA berkaitan yang sangat erat dengan konsep pemahaman IPA secara terstruktur, sehingga Ilmu Pengetahuan Alam (IPA) tidak sebatas pada kemampuan hasil belajar tetpi ebih kepada keterampilan siswa. Uraian tersebut menegaskan bahwa pembelajaran IPA hendaknya sangat bermanfaat bagi siswa terutama dalam perkembngan siswa. Hal ini juga memberikan penegasan bahwa pentingnya peranan ilmu IPA bagi siswa.

Kurikulum K-13 Revisi pada kenyataannya tidak semuanya berjalan dengan lancar. Pada beberapa sekolah yang menjadi tempat observasi, sekolah memiliki bebarapa permasalahan mengenai laboratorium diantaranya, sekolah tidak memiliki laboratorium, sekolah memliki laboaratorum tetapi tidak digunakan dengan baiak, sekolah memiliki laboaratorium tetapi alat dan bahan yang digunakan tidak mencukupi, dan sekolah memiliki laboratorium tetapi tidak memiliki laboran. Sehingga 
pada penelitian ini, akan dirancang dan dikembangkan buku ajar IPA terpadu berbasis eksprimen SMP/MTs.

Keterampilan proses sains (KPS) dan karakteristiknya tidak dapat dipisahkan, tetapi ada penekanan yang utama dalam KPS tersebut. Pendapat Dimyati dan Mudjiono (2013: 140) bahwa "ada berbagai keterampilan dalam keterampilan proses, keterampilan-keterampilan tersebut terdiri dari keterampilan-keterampilan dasar (basic skills) dan keterampilanketerampilan terintegrasi (integrated skills)". Kemudian Depdikbud dalam Dimyati dan Mudjiono (2013: 141) "adapun tujuh keterampilan proses sians (KPS) tersebut adalah mengamati, menggolongkan, menafsirkan, meramlkan, menerapkan, merencanakan, penelitian, dan mengkomunikasikan.

Menurut Hamdani (2011: 120) buku ajar merupakan gumpulan materimateri yang tersusun secara sistematis yang di buat oleh ahlinya dan diguanakan oleh guru dan siswa dalam proses belajar mengajar dikelas. Bahan ajar sangat bermanfaat bagi siswa. Siswa dapat memahami materi pelajaran dengan baik dengan di bantu oleh buku ajar ataupun media pembelajaran, siswa dengan adanya bahan ajar membuat nilai belajarnya lebih baik.

Selanjutnya menurut Daryanto (2013: 9) "Modul merupakan salah satu bentuk bahan ajar yang dikemas secara utuh dan sistematis, didalamnya memuat seperangkat pengalaman belajar yang terencana dan didesain untuk membantu peserta didik menguasai tujuan belajar yang spesifik". Menurut Depdiknas (2010), modul merupakan bagian dari materi utama yang dibuat secara sistematis, dan dirancang sesuai dengan kebutuhan. Sedangkan Nasution (2013:205), modul merupakan gumpulan materi yang ingin di capai oleh sisiwa dalam pembelajaran. Berdasarkan analisis di atas dapat dibuat kesimpulkan bahwa modul merupakan gumpulan lemabaran kertas yang dicetak menjadi satu yang digunakan sebagai media dalam proses pembelajan yang terdiri dari indicator, tujuan, rumusan maslaah, materi, latihan soal, rangkuman, dan soal.

Berdasarkan hasil pengamatan yang dilakukan oleh penulis pembelajaran IPA terpadu di SMP N 1 Sungai Kakap Kab. Kubu Raya masih kurang baik. Salah satunya penyebabnya adalah kurang ketersediaan media yang digunakan dalam pembelajaran. Guru jarang sekali mengguana media pembelajaran dalam pembelajaran di kelas. Buku paket yang digunakan guru masih menggunakan buku paket yang berasal dari luar Kalimantan Barat. Sehingga proses pembelajaran di kelas menjadi kurang efektif.

Lembaga kependidikan dituntut untuk dapat berperan aktif lebih luas menyangkut upaya untuk menghasilkan kehidupan yang lebih bermartabat dengan adanya perkembangan sains teknologi lingkungan dan masyarakat yang sedang berlangsung keterkaitanya dengan dunia pendidikan. Hal ini menunjukkan bahwa lembaga kependidikan khususnya pada jenjang perguruan tinggi diharapkan dapat merancang sendiri perangkat pembelajaran yang diperlukan untuk keberlangsungan proses pembelajaran di 
tingkat satuan pendidikan diantaranya SMP.

Trianto (2012:89) menyatakan kemapuan daya tangkap seseorang lebih tinggi jika dilakukan dengan melihat, mendengarkan dan melakukan. Berdasarkan hal tersebut, buku ajar Ilmu Pengetahuan Alam (IPA) Terpadu menjadi bahan ajar yang efektif karena buku ajar yang di kembangkan akan siswa lihat, baca, dan dengarkan. menurut Winkel W.S (2009) pembelajaran yang menarik dikelas jika pembelajaran lebih di uataman pembelajaran yang membuat siswa lebih aktif, siswa bisa belajar kapan dan dimanapun dan pembelajaran secaar ceramah lebih cendrung dikurangi. Dengan adanya buku membuat siswa lebih mudah membawa buku ajar sehingga kapan dan dimanapun buku ajar tersebut bisa digunakan, baik dikelas, dirumah, maupun di lingkunganya.

Permasalalahan yang terjadi pada kegiatan belajar mengajar membuat guru bisa menggunakan buku ajar yang inovatif dan tepat..

Pengembangan buku ajar yang baik, jika tidak diimbangi dengan pelaksanaan pembelajaran di dalam kelas, tentunya tidak akan membantu mahasiswa dalam mencapai kompetensi yang ingin dicapai. Buku ajar IPA SMP berbasis eksperimen merupakan suatu pengembangan buku ajar yang dikaitkan strategi pelaksanaan pembelajaran dikelas yang aktif, inofatif, efektif dan menarik. Pengembangan buku ajar berbasis eksprimen merupakan pengembangan buku ajar yang membantu mahasiswa dalam membangun informasi (pengetahuan) dalam memahami konsep melalui percobaan (eksprimen) pada pelajaran IPA kelas VII SMP yang disampaikan. Hal ini sesuai dengan perencanaan $\mathrm{K}$ 13, dimana pelaksanaan pembelajaran di dalam kelas dilaksanakan dengan pendekatan Scientific Approach yang meliputi observing (mengamati), questioning (bertanya), experimenting (eksprimen), associating (diskusi), dan networking (presentasi). Dengan demikian, perlu dilakukan penelitian pengembangan buku ajar IPA berbasis eksprimen (Kemendikbud, 2017).

\section{METODE}

Bentuk penelitian yaitu penelitian dan pengembangan dengan model four-d yang terdiri dari:

\section{Define}

a. Analisis Materi

Dilakukan terhadap analisis materi untuk mengetahui kebutuhan sumber belajar berupa buku bagi siswa SMPN 01 Sungai kakap kelas VII, mengetahui hubungan antara materi satu dengan yang lainnya.

\section{b. Analisis Karakteristik siswa}

Tujuan untuk mengetahui ciri khas siswa pada saat sebelum dilakukan penelitian. Mengetahui minat baca dan minat untuk belajar secara mandiri dan keinginan untuk membaca buku ajar. siswa masih belum mempunyai buku ajar IPA SMP Kelas VII berbasis eksprimen. Instrumen berupa lembar wawancara. Obyek wawancara adalah sebagian siswa kelas VII SMP N 01 Sungai Kakap.

\section{c. Analisis Materi}

Materi yang dikembangkan disesuaikan dengan indikator yang telah ditetapkan pada analisis kurikulum. Sumber materi dikumpulkan dan dipilih 
dari buku yang relevan, Materi yang telah dikumpulkan akan disusun secara sistematis berdasarkan indikator. Selain materi dilakukan pula pengumpulan gambar, artikel dan desain layout.

\section{d. Merumuskan Tujuan} merumuskan tujuan pembelajaran dan indikator yang ingin dicapai. Hal ini bertujuan supaya peneliti tidak menyimpang dari tujuan semula pada saat penulisan buku ajar.

\section{Tahap Perancangan (Design)}

\section{a. Pembuatan Draf Produk}

Langkah pertama yaitu pembuatan layout untuk cover dan isi buku ajar. Berikut rancangan buku ajar IPA berbasis eksperimen.

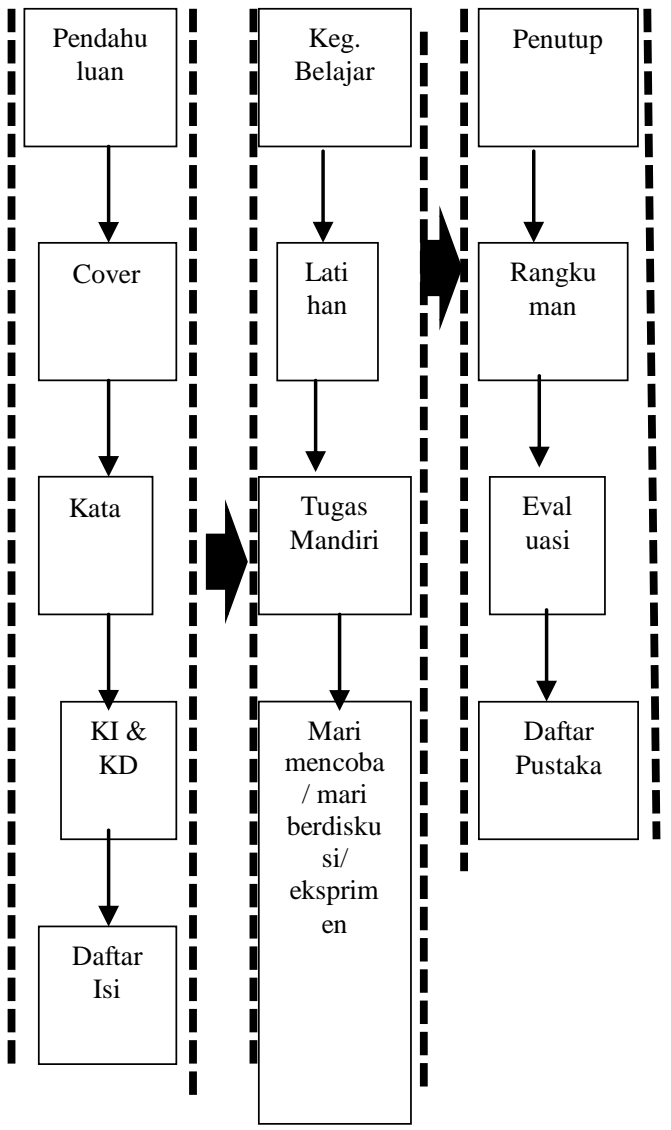

Gambar 1. Desain buku ajar IPA SMP Kelas VII berbasis eksprimen
Kreativitas peneliti sangat diperlukan dalam tahapan ini, dan desain layout disesuaikan dengan karakteristik siswa supaya buku ajar yang dibuat sesuai dengan yang diharapkan siswa. Selanjutnya, mengkolaborasikan antara gambar dan teks dengan layout yang telah dibuat. Dalam hal ini perlu diperhatikan warna, ukuran, dan tipe huruf serta tata letak antara huruf dan gambar. Kemudian, dilakukan editing secara teliti dan menyeluruh, baik dari segi bahasa, penulisan, tata letak, maupun layout. Langkah terakhir adalah finishing, dalam tahap ini dilakukan pencetakan buku ajar elektronika digital berbasis eksprimen yang telah dikembangkan sesuai dengan ukuran yang telah dirancang.

b. Validasi

Produk yang sudah dikembangkan akan di validasi leh validator ahli materi, bahasa dan gambar serta kegrafisan. Hasil dari tahap validasi akan didapatkan hasil validasi berupa nilai dan komentar vakidator sebagai bahan perbaikan buku ajar.

\section{c. Revisi}

Revisi merupakan perbaikan draf buku ajar yang dibuat. Revisi dilakukan apabila validator menilai bahwa draf buku ajar yang dibuat masih terdapat kekurangan. Apabila validator ahli materi maupun media menyatakan draf buku ajar telah baik, maka tidak perlu melakukan revisi. Setelah melakukan revisi dari validator, maka draf buku ajar siap untuk diujikan ke siswa dalam uji coba awal.

3. Tahap pengembangan

a. Uji Coba Awal

Draf buku ajar yang sudah dikatakan baik oleh validator 
kemudian diujicobakan ke siswa. Uji coba awal merupakan uji coba yang melibatkan 10 siswa SMPN 01 Sungai Kakap kleas VII. Tahapan ini dilaksanakan dengan memberikan angket penilaian produk kepada siswa terkait aspek materi, bahasa dan gambar, penyajian, serta tampilan, sehingga diperoleh respon siswa terkait kriteria buku ajar IPA terpadu berbasis eksprimen. Setelah uji coba awal dilakukan, tahap selanjutnya adalah revisi. Revisi perbaikan akan dilakukan berdasarkan saran dan kekurangan yang terdapat pada draf buku ajar saat diujicobakan dilakukan.

\section{b. Uji Coba Utama}

Dilaksnakan ke seluruh siswa SMPN 01 Sungai Kakap Kelas VII yang mengambil mata kuliah IPA terpadu. Tahapan ini dilaksanakan dengan memberikan instrument angket penilaian produk kepada siswa terkait aspek materi, bahasa dan gambar, penyajian serta tampilan, sehingga diperoleh respon mahasiswa terkait kriteria buku ajar elektronika digital berbasis eksprimen.

Kemudian, langkah terakhir yang dilakukan adalah revisi dari para ahli serta analisis untuk menyempurnakan produk yang dihasilkan. Revisi dilakukan berdasarkan saran dan jika terdapat kekurangan pada produk buku ajar saat uji coba utama dilakukan. Setelah revisi dan analisis selesai, maka diperoleh produk akhir dari buku ajar IPA SMP Kelas VII berbasis eksprimen.

\section{Tahap Penyebarluasan (Disseminate)}

Tahapann ini dilakauan dengan memberikan buku ajar IPA Terpadu berbasis eksprimen kepada siswa dan guru dengan jumlah terbatas

\section{HASIL DAN PEMBAHASAN}

Penelitian Pengembangan

Buku Ajar IPA Terpadu SMP Berbasis eksprimen ini dilakukan dimulai dari tahap analisis kebutuhan penelitian (research) dan pengembangan produk (development) serta pembuatan desain. Berdasarkan tujuan penelitian yaitu untuk menilai kelayakan buku ajar IPA terpadu SMP/MTs berbasis eksprimen menurut ahli materi dan untuk mengetahui kelayakan buku ajar IPA terpadu SMP/MTs berbasis eksprimen menurut ahli media. Untuk penilaian validator ahli, yang dapat digunakan sebagai panduan layak atau tidaknya buku ajar IPA terpadu SMP berbasis eksprimen dengan memberikan angket kelayakan kepada ahli materi dan media.

\section{Kelayakan Media Pembelajaran Menurut Ahli Materi}

Buku ajar yang dikembangkan digunakan oleh sekolah, produk divalidasi terlebih dahulu validator ahli materi. Validasi ini dilakukan agar produk buku ajar yang dikembangkan mendapatkan jaminan bahwa materi yang terdapat dalam buku ajar IPA terpadu berbasis eksprimen tidak mengalammi kesalahan konsep dan layak digunakan oleh siswa. Selain itu validasi ahli materi berguna untuk mengantisipasi kesalahan materi, kekurangan materi, dan antisipasi saat penggunaan buku ajar di sekolah. Validasi ahli materi dilakukan agar produk yang dikembangkan tidak mengalami banyak kesalahan dan sesuai dengan kebutuhan siswa disekolah.

Validator ahli materi dalam validasi buku ajar IPA terpadu SMP berbasis eksprimen yaitu 1 orang dosen Program Studi Pendidikan Fisika yang ahli di bidang materi. Validasi ahli materi dilakukan dengan memberikan buku ajar beserta lembar penilaian. Lembar penilaian berupa lembar 
validasi dengan 54 butir soal tentang aspek kelayakan isi, aspek kelayakan penyajian, penilaian bahasa, dan penilaian model eksprimen validator ahli materi akan menilai buku ajar IPA terpadu SMP/MTs yang telah di kembangkan sesuai dengan lembar penilaian yang telah diberikan.

Proses penilaian terhadap validator ahli materi pada buku ajar IPA terpadu SMP berbasis eksprimen yang telah dikembangkan. Berikut tabel 1 hasil penilaian ahli materi berdasarkan tiap aspek yang di gunakan. Dari perhitungan table 1 pada ke 4 indikator yang telah diuraikan diatas dapat disimpulkan bahwa berdasarkan aspek Materi mendapatkan rata-rata nilai 72.17 dengan kriteria layak, aspek isi mendapatkan rata-rata nilai 69.04, aspek penyajian mendapatkan nilai rata-rata 69.64, aspek bahasa dan eksprimen mendapatkan nilai rata-rata 75.00. Nilai untuk tiap aspek dapat dilihat pada Tabel 1.

Tabel 1. Nilai tiap aspek ahli materi

\begin{tabular}{cccc}
\hline Validator & Aspek & Nilai & Keteria \\
\hline & Isi & 69.04 & \\
Ahli & Penyajian & 69.64 & \\
Materi & Bahasa & 75.00 & \\
& Eksprimen & 75.00 & \\
Rata-rata & 72.17 & Layak \\
\hline
\end{tabular}

Berdasarkan dari data Tabel 1, buku ajar IPA terpadu SMP berbasis eksprimen dikatakatan sangat layak dari segi aspek isi, penyajian, bahasa, dan eksprimen. Sehingga buku ajar IPA terpadu SMP berbasis eksprimen layak digunakan dalam proses pembelajaran.

Seiring dengan Tabel 1 di atas, hasil revisi ahli materi dapat dilihat pada Tabel 2 berikut ini.
Tabel 2. Hasil revisi ahli materi

\begin{tabular}{|c|c|c|}
\hline No. & Sebelum Revisi & Sesudah Revisi \\
\hline 1 & $\begin{array}{l}\text { Berdasarkan } \\
\text { penilaian validator } \\
\text { sebaiknya contoh } \\
\text { soal dibuat lebih } \\
\text { akurat sesauai } \\
\text { dengan indikator }\end{array}$ & $\begin{array}{l}\text { Memperbaiki soal } \\
\text { lebih akurat lagi }\end{array}$ \\
\hline 2 & $\begin{array}{l}\text { Berdasarkan } \\
\text { penilaian validator } \\
\text { bahwa buku ajar } \\
\text { yang } \\
\text { dikembangkan } \\
\text { acuan pustakanya } \\
\text { masih belum akurat }\end{array}$ & $\begin{array}{l}\text { Mencari acuan } \\
\text { pustaka untuk } \\
\text { pengembngan } \\
\text { buku ajar agar } \\
\text { relevan }\end{array}$ \\
\hline 3 & $\begin{array}{l}\text { Berdasarkan } \\
\text { penilaian validator } \\
\text { bahwa buku ajar } \\
\text { yang } \\
\text { dikembangkan } \\
\text { perlu } \\
\text { menambahkan } \\
\text { gambar dan } \\
\text { ilustrasi aktual }\end{array}$ & $\begin{array}{l}\text { Menambahkan } \\
\text { gambar dan } \\
\text { ilustrasi aktual } \\
\text { sesuai dengan } \\
\text { jenjang pendidikan } \\
\text { siswa. }\end{array}$ \\
\hline 4 & $\begin{array}{l}\text { Berdasarkan } \\
\text { penilaian validator } \\
\text { bahwa tampilan } \\
\text { buku ajar yang } \\
\text { dikembangkan } \\
\text { masih kurang } \\
\text { menarik }\end{array}$ & $\begin{array}{l}\text { Membuat tampilan } \\
\text { buku ajar lebih } \\
\text { menarik lagi. }\end{array}$ \\
\hline
\end{tabular}

Dari hasil revisi yang dilakukan oleh validator ahli media dilakukan perbaikan dengan memperhatikan saran dan masukan para ahli materi. Setalah di perbaiki tahapan selanjutnya adalah penyempurnaan dari buku ajat tersebut.

Berdasarkan validasi oleh ahli materi untuk buku ajar IPA terpadu SMP berbasis eksprimen ada perbaikan pada bagian materi yang telah di buat. Setelah bagian materi di perbaiki maka materi dikatakan layak digunakan. Berikut hasil perbaikan yang dilakukan.

\section{Kelayakan Media Pembelajaran Menurut Ahli Media}

Sebelum produk di uji cobakan ke lapangan, produk di validasi terlebih dahulu oleh ahli media. Validasi media dilakukan penilaian berdasarkan sudut pandang media yang tertuang di dalam 
buku ajar IPA terpadu SMP berbasis eksprimen. Validasi ini di lakukan agar produk buku ajar IPA terpadu SMP berbasis eksprimen yang di kembangkan dapat di katakan layak dan dapat di ujicobakan terhadap siswa. Selain itu validasi ahli media bermanfaat dalam mengantisipasi kesalahan dalam menampilkan gambar, kekurangan materi, antisipasi saat di ujicoba di lapangan dan lain-lain. Selain desain produk di selesaikan, desain produk tersebut dapat di serahkan kepada validator untuk di validasi dan di nilai kelayakannya.

Validator ahli media yaitu 1 orang dosen Program Studi Pendidikan Biologi.Validasi ahli media di lakukan dengan memberikan buku ajar IPA terpadu SMP/MTs beserta lembar penilaian. Intrumen penilaian merupakan instrument anket yang terdiri dari 31 soal.

Setelah dilakukan validasi pada buku ajar dapat diketahui tidak ada revisi yang terlalu signifikan pada buku ajar IPA terpadu SMP berbasis eksprimen.

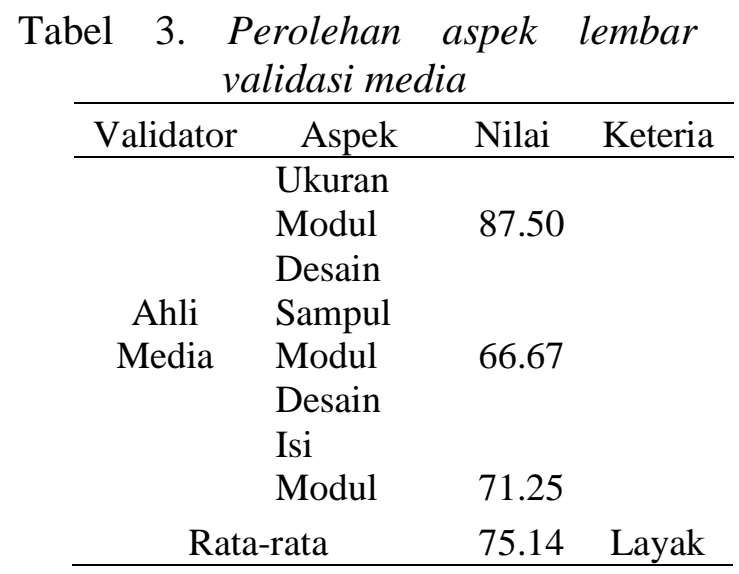

Dari data di atas, dapat dinyatakan bahwa buku ajar IPA terpadu SMP berbasis eksprimen dikatakatan layak dari segi tampilan dan tata letak. Sehingga buku ajar IPA terpadu SMP berbasis eksprimen dikatakan layak digunakan dalam proses pembelajaran. Berdasarkan validasi oleh ahli madia untuk buku ajar IPA terpadu SMP berbasis eksprimen ada perbaikan pada bagian tampilan yang telah di buat. Setelah bagian media diperbaiki maka buku ajar dikatakan layak digunakan.

Berikut hasil perbaikan dapat dilihat pada Tabel 4 di bawah ini.

\begin{tabular}{|c|c|c|}
\hline No. & $\begin{array}{l}\text { Sebelum } \\
\text { Revisi }\end{array}$ & $\begin{array}{c}\text { Sesudah } \\
\text { Revisi }\end{array}$ \\
\hline 1 & $\begin{array}{l}\text { Teks yang } \\
\text { digunakan } \\
\text { ukurannya } \\
\text { terlalu besar, } \\
\text { dan } \\
\text { background } \\
\text { kurang } \\
\text { menarik }\end{array}$ & $\begin{array}{l}\text { Memperbaiki } \\
\text { ukuran teks } \\
\text { menjadi } 12 \\
\text { dan membuat } \\
\text { background } \\
\text { menjadi } \\
\text { menarik }\end{array}$ \\
\hline 2 & $\begin{array}{l}\text { Pembuatan } \\
\text { halaman } \\
\text { harus } \\
\text { konsisten, } \\
\text { penambhan } \\
\text { logo institusi, } \\
\text { penambahaan } \\
\text { ilustrasi } \\
\text { gambar, dan } \\
\text { penggunaan } \\
\text { warna lebih } \\
\text { berani. }\end{array}$ & $\begin{array}{l}\text { Membuat } \\
\text { halaman lebih } \\
\text { konsisten, } \\
\text { menambahkan } \\
\text { logo IKIP } \\
\text { PGRI } \\
\text { Pontianak } \\
\text { pada sampul, } \\
\text { menambahkan } \\
\text { ilustrasi } \\
\text { gambar } \\
\text { dengang } \\
\text { menambahkan } \\
\text { warna yang } \\
\text { menarik. }\end{array}$ \\
\hline 3 & $\begin{array}{l}\text { Belum } \\
\text { adanya } \\
\text { penulis } \\
\text { dalam } \\
\text { sampul buku } \\
\text { ajar, daftar } \\
\text { isi, dan kata } \\
\text { pengantar. }\end{array}$ & $\begin{array}{l}\text { Menambahkan } \\
\text { penulis dalam } \\
\text { cover, } \\
\text { membuat } \\
\text { daftar isi dan } \\
\text { kata } \\
\text { pengantar. }\end{array}$ \\
\hline
\end{tabular}

Dari perhitungan Tabel 4, ke 3 aspek di atas dapat disimpulkan bahwa mendapatkan nilai 75.14 dengan kriteria layak, aspek ukuran modul mendapatkan nilai rata-rata skor 87.50 , 
meraut bagian isi bamboo tersebut. Jumlah senarnya tergantung kepada dari selera pembuat atau oaring yang memesan instrument, dapat berjumlah 2 sampai 5. Nada di setiap senar bergantung pada tegangan senar yang ditentukan oleh peletakkan gripnya. Ntunikng bisanya dimainkan untuk mengiringi permainan pencak silat atau seni bela diri khas Dayak Mali. Pemaian seni music Ntunikng adalah pewaris sekaligus pelaku kisah sejarah Kapupaten Mali.

Dengan adanya Buku ajar IPA terpadu SMP/Mts berbasis eksprimen membuat siswa lebih memahami konsep IPA yang ada di dalam buku, selaian itu membuat siswa lebih mencintai kearifan local di suatu daerah. Banyak sekali siswa yang tidak mengetahui jenis alat music local yang mengandung konsep IPA, ternyaa banyak sekali konsep yang ada pada alat music daerah.

Buku ajar IPA terpadu SMP/Mts berbasis eksprimen selaian menekankan konsep kearifan local Kalimantan Barat juga menenkankan eksprimen. Siswa di ajak untuk terjun langsung mengamati fenomena yang ada di daerah atau di laboaratorium. Alat dan bahan yang tersedia di alam Kalimantan abarat dimanfaatkan untuk proses pembelajaran di kelas. Dengan hal ini membuat siswa tertarik dan termotifasi dengan pembelajaran IPA. Pembelajaran IPA terpadu pada prinsipnya bukan pembajaran yang sulit. Pembelajaran IPA terpadu akan menjadi sulit jika penyajian pembelajaran di kelas tidak melihat karakteristik siswa dan sekolah. Karakteristik siswa atau asal siswa, mata pencarian orang tua siswa sangat berpengaruh terhadap daya serap anak. Anak yang sehariannya berkecimpung dalam dunia nelayan akan sulit memahami jika kita menjelaskan tentang pesawat terbang, dan akan mudah diterima jika kita menjelaskan mengenai motor air untuk menagkap ikan. Karakteristik siswa sangat penting untuk pembelajaran siswa di kelas.

Kearifan local harus di libatkan dalam pembelajaran IPA terpadu di sekolah. Banyak sekali konsep konsep IPA terpadu yang terdapat di daerah sekolah tersebut berada. Setiap sekolah memiliki kearifan local masing-masing. Pemanfaat kearifan local baik, alam, budaya, maupaun adat istiadat dapat kita jadaikan sebagai media pembelajaran yang murah, meriah, dan bermakna.

Menurut Nieeven (2010), suatu media belajar bermanfaat jika hasil dari penggunaan media tersebut membuat Prestasi belajar siswa meningkat meliputi tiga aspek yaitu pengetahuan, keterampilan, dan sikap.

\section{KESIMPULAN} adalah:

Kesimpulan dari penelitian ini

1. Buku ajar IPA terpadu SMP berbasis eksprimen yang telah di validasi ahli validator materi dengan nilai rata-rata 72.17 dengan keteria layak digunakan.

2. Buku ajar IPA terpadu SMP berbasis eksprimen yang telah di validasi oleh ahli media dengan keteria layak digunakan dengan nilai rata-rata 75.14 .

\section{DAFTAR PUSTAKA}

Ani C, \& Hartono. 2015. Analisis Ilustrasi Gambar pada Buku Teks Fisika Kelas XI yang Banyak Digunakan di SMA Negeri SeKabupaten Demak. Unnes Physics Education Journal 4 (3), 17-25.

Azwar, S., 2013. Pengembangan Buku Ajar. Yogyakarta: Pustaka Pelajar.

Budi Setyawan, S. 2012. Pengembangan LKS IPA Terpadu Berbasis 
Inkuiri Terbimbing pada Tema Sistem Kehidupan dalam Tumbuhan Kelas VIII di SMP N 2 Playen. Jurnal Pendidikan IPA FMIPA UNY, 1 (4): 1-6.

Daryanto. 2013. Menyusun Modul. Yogyakarta: Grava Media.

Depdiknas. 2010. Teknik Penyusunan Modul. Jakarta: Direktorat Jendral Manajemen Pendidikan Dasar dan Menengah. Depdiknas. 2010. Teknik.

Hamdani. 2011. Strategi Belajar Mengajar. Bandung: Pustaka Setia.

Kanematsu, H., \& Barry, D. M. 2016. STEM and ICT Education in Intelligent Environments. London: Springer International Publishing Switzerland.

Kemenristekdikti. 2018. Kebijakan Kemenristekdikti Menghadapi Globalisasi Pendidikan \& Revolusi Industri 4.0 [Press release].

Kemristekdikti. 2017. Panduan Teknis Indikator Kinerja Pengembangan Pusat Unggulan Iptek Tahun 2017. Jakarta: Direktorat Jenderal Kelembagaan Iptek dan Dikti.

Kemristekdikti. 2018. Pengembangan Iptek dan Pendidikan Tinggi di Era Revolusi Industri 4.0. Retrieved from https://www.ristekdikti.go.id/pen gembangan-iptek-danpendidikan-tinggi-di-erarevolusi-industri-4-0/

Kemristekti. 2018. Presiden Jokowi: Tantangan Kita Kedepan, Revolusi Industri 4.0. Retrieved from

https://www.ristekdikti.go.id/ presiden-jokowi-tantangan-kitakedepanrevolusi-industri-4-0/

Kemendikbud. 2017. Modul Silabus Mata Pelajaran Sekolah Menengah Pertama/Madrasah
Tsanawiyah (SMP/MTs). Jakarta: Kemendikbud.

Leonardo, S. (2016). Perancangan Buku Ilustrasi Pengenalan Nama BuahBuahan dengan Sistem Isyarat Bahasan Indonesia Berbasis karaketr untuk Anakanak TKLB-B Karya Mulia Surabaya. (Thesis tidak dibulpikasikan). Surabaya. : Institus Bisnis dan Infirmatika STIKOM Surabaya.

Mudjiono. 2013. Belajar dan Pembelajaran. Jakarta: Rineka Cipta.

Nasution Nasution. 2011. Berbagai Pendekatan dalam Proses Belajar dan Mengajar. Bandung: Bumi Aksara.

Nieveen, Nieke. 2010. Formative Evaluation in Educational Desaign research. An Intruduction to Educational desaign research. Enshede: Netherlands Institute for Curriculume Development (SLO).

Prastowo, Andi. 2011. Panuan Keratif Membuat Bahan Ajar Inovatif. Yogyakarya: DIVA Press.

Rahmawati, F. 2010. Strategi Pencapaian Kualitas Pembelajaran. (http:// www.google.com diakses 15/12/ 2018

Soedarso, N. 2014. Perancangan Buku Ilustrasi Mahapatih Gajah Mada. Humaniora 5 (2), 561570. Undang - undang Republik Inonesia No. 14

Sugiono. 2015. Metode Penelitian Manajemen. Bandung: Alfabeta

Sugiyono. 2016. Metode Penelitian Kuantitatif Kualitataif dan Kombinasi (Mixed Methods). Bandung: Alfabe

Susilo, Ibrahim and Suwono. 2017 Patrap Triloka ethno 
pedagogy with ResearchBased Learning Settings to Develop Capability of PreService Science Teachers: Literature Review. Paper presented at the 1 st Internasional Conference on Mathematics, Science, and Education (ICoMSE 2013), Malang.

Trianto. 2012. Model Pembelajaran

Terpadu dalam Teori dan Praktek. Jakarta: Kencana Prenata Media Group

Winkel, W.S. 2009. Psikologi Pengajaran. Jakarta: Grasindo 